\title{
The impact of European Monetary Union on finance-growth Nexus
}

\begin{abstract}
This study examines the relationship between financial development and economic growth in 15 developed European countries before and after the formation of the euro. The results of the panel data analysis show that financial development is significant in promoting economic growth for both periods. The impact of the banking sector development on growth, however, is greater in the post-euro period, whereas the impact of stock market development on growth is reducing in the period investigated. The study concludes that the formation of European Monetary Union does not weaken the relationship between financial development and economic growth in developed European countries.
\end{abstract}

Keyword: Financial development; Economic growth; European Monetary Union; Panel data analysis 